\title{
Effects of Vasoactive Intestinal Peptide on Glycogenolysis in Cultured Liver Cells
}

\author{
Mitsuhiro MAtSUmUra, Hiroto AKIYOSHI*, Shiro SAITO**, \\ AND HIROYOSHI MORI
}

\begin{abstract}
Department of the Second Internal Medicine, School of Medicine, Tokushima University, Kuramoto-cho, Tokushima, Tokushima 770
\end{abstract}

\section{Synopsis}

When isolated rat liver cells were incubated in the presence of vasoactive intestinal peptide at the concentrations ranging from $0.2 \mu \mathrm{g}$ to $2 \mu \mathrm{g}$ per $\mathrm{m} l$, glycogenolysis was maximally stimulated within $15 \mathrm{~min}$. However, somatostatin inhibited the liver glycogenolysis. The combined addition to the incubation medium showed that insulin and somatostatin inhibited the stimulated glycogenolysis induced by vasoactive intestinal peptide, while vasoactive intestinal peptide plus secretin showed no additive effect on glycogenolysis, as compared with single the addition of vasoactive intestinal peptide. On the other hand, the addition of glucagon to vasoactive intestinal peptide showed additive effects on glycogenolysis. These results suggest that the receptor site for vasoactive intestinal peptide may be distinguishable from that for glucagon. Extracellular calcium ions were demonstrated to play an important role in the modulation of vasoactive intestinal peptide-induced glycogenolysis.

The evidence presented in this paper indicates that glucose metabolism may be partly regulated by the direct action of vasoactive intestinal peptide on hepatocytes, which is referred to as an enterohepatic axis and that the axis is inhibited by insulin and somatostatin.

Vasoactive intestinal peptide (VIP) was isolated from the porcine small intestine (Said and Mutt, 1970) and shown to have an amino acid sequence related to that of secretin, glucagon and gastric inhibitory polypeptide (Grossman, 1974). VIP has a wide spectrum of biological activities, including a positive ionotropic action on the heart (Said et al., 1972), smooth muscle relaxation (Piper et al., 1970), stimlation of pancreatic secretion (Said and Mutt, 1972), inhibition of gastric serection (Schorr et al., 1974), lipolysis (Frandsen and

\footnotetext{
Received August 9, 1978.

* Department of Enzyme Physiology, Institute for Enzyme Research, School of Medicine, Tokushima University, Tokushima 770.

** Department of Laboratory Medicine, School of Medicine, Tokushima University, Tokushima 770.
}

Moody, 1973) and glycogenolysis (Kerins and Said, 1973). With respect to carbohydrate metabolism, it has been reported that VIP elevates serum glucose levels by inducing insulin and glucagon release through the enteroinsular axis (Unger et al., 1976) and stimulates glycogenolysis in rabbit liver slices (Kerins and Said, 1973).

Desbuquois et al. (1973) and Bataille et al. (1974) demonstrated that the specific receptor sites for VIP and secretin were identical and located on liver cell membranes, but differed from those for glucagon. Although this receptor has not been found in the isolated hepatocytes, these findings suggest that VIP and secretin may have some direct effects on the glucose metabolism in hepatocytes.

The results of the present work has raised 
a possibility that serum glucose levels are not only regulated by the enteroinsular axis, but also by the enterohepatic axis through direct actions of VIP, secretin and glucagon on glucose synthesis in the liver. This paper also demonstrates results which suggest that the biological receptor site for VIP may be distinguished from that for glucagon and that calcium ions may play an important role in VIP-induced glycogenolysis.

\section{Materials and Methods}

\section{Materials}

Male rats of the Wistar-King strain, weighing ca. $250 \mathrm{~g}$, were used for the preparation of single liver cells. Glucagon and collagenase were obtained from Sigma Chemical Co., U.S.A. Synthetic materials such as vasoactive intestinal peptide (VIP) and secretin were the generous gifts from Prof. N. Yanaihara, Shizuoka College of Pharmacy, Shizuoka. Synthetic somatostatin was purchased from the Protein Research Foundation, Osaka.

\section{Methods}

Hepatocytes were isolated from the liver of wellfed rats by the method of Berry and Friend (1969) with some modifications. The rat liver was perfused through the portal vein with $50 \mathrm{~m} l$ of Hanks solution. Then the liver was removed, cut into slices with a razor in a cold room and suspended in $15 \mathrm{ml}$ of digestive solution composed of $0.05 \mathrm{~g} / \mathrm{ml}$ of collagenase and $2 \mathrm{~g} / \mathrm{ml}$ of bovine albumin in calciumfree Hanks solution containing $10 \mathrm{mM}$ Hepes $(\mathrm{pH}$ 8.0). The suspension was incubated in a $200 \mathrm{ml}$ Erlenmeyer flask for $30 \mathrm{~min}$ at $37^{\circ}$ under $95 \% \mathrm{O}_{2}$ and $5 \% \mathrm{CO}_{2}$ with constant shaking. After incubation the detached cells were collected and centrifuged at $50 \times \mathrm{g}$ for $30 \mathrm{~s}$. Hepatocytes in the pellet were washed twice with Hanks solution and finally suspended so as to have the cell density of $2 \times 10^{6} / \mathrm{ml}$ in Krebs-Ringer bicarbonate buffer. Cell viability was monitored by the trypan blue staining of the dead cells.

For the study of glycogenolysis, the cell suspension $(1 \mathrm{~m} l)$ was incubated at $37^{\circ}$ for the indicated period with constant and mild shaking with or without the addition of various hormones. After incubation the cell suspension was sonicated to disrupt cell membranes. Glucose content of the reaction mixture was measured by the glucose oxidation method. Values in the tables indicate the means \pm S.E.M. of the four experiments. The data were analysed by the Student's $t$ test, the criterion for significance being $\mathrm{p}<0.05$ (Hill, 1967).

\section{Results}

Time course of glycogenolysis induced by vasoactive intestinal peptide in cultured liver cells

As shown in Fig. 1, the liver glycogenolysis reached a maximum level about $15 \mathrm{~min}$ after incubation with $2.0 \mu \mathrm{g} / \mathrm{m} l$ of VIP. Therefore, the incubation time of $15 \mathrm{~min}$ was adopted for the further experiments.

glycogenolysis in response to VIP doses in cultured liver cells

When liver cells were incubated for 15 min in the presence of VIP, the increases of glucose production were observed (Table 1). VIP showed a stimulatory effect on glycogenolysis at the concentrations ranging from $0.2 \mu \mathrm{g} / \mathrm{m} l$ to $2.0 \mu \mathrm{g} / \mathrm{m} l$ with the increase rates of 20 to $67 \%$.

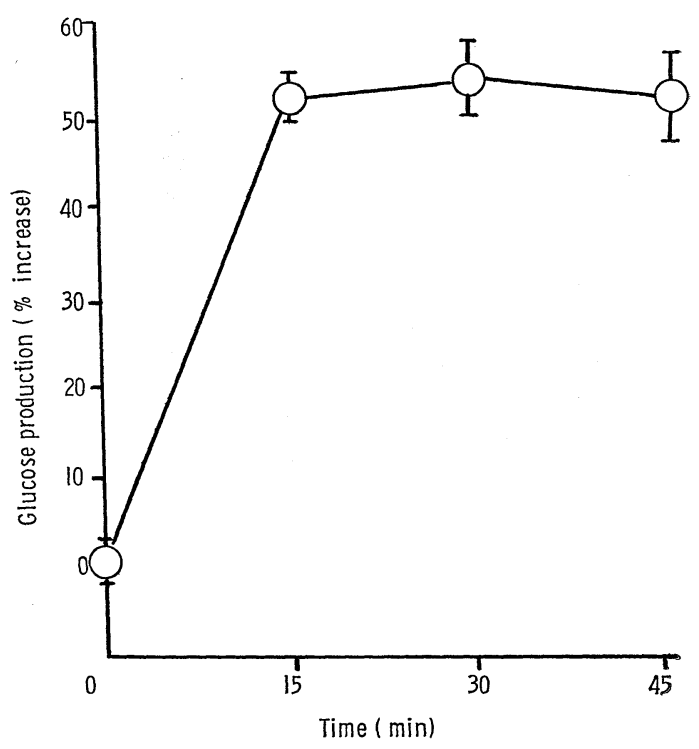

Fig. 1. Time course of glycogenolysis induced by vasoactive intestinal peptide in cultured liver cells. 
Additive effects of VIP, secretin, and glucagon on glycogenolysis

As shown in Table 2, the single addition of $0.2 \mu \mathrm{g} / \mathrm{m} l$ VIP, $2.0 \mu \mathrm{g} / \mathrm{m} l$ secretin, and $0.2 \mu \mathrm{g} / \mathrm{ml}$ glucagon stimulated glycogenolysis by $29 \%, 30 \%$ and $45 \%$, respectively. On the other hand, a combination of the same concentrations of VIP and secretin caused a 34\% increase in glucose synthesis. A combination of VIP and glucagon at the same concentrations caused a $69 \%$ increase.

Effects of insulin and somatostatin on VIP-induced glycogenolysis

Table 3 shows that somatostatin alone was inhibitory for glycogenolysis and that slight but significant suppression of VIPinduced glycogenolysis was also observed with addition of somatostatin (about 13\% inhibition). Insulin was found to be a strong inhibitor for both basal and VIPinduced glycogenolysis.

Calcium ion dependency of VIP-induced glycogenolysis

We examined the effect of Verapamil, an inhibitor of $\mathrm{Ca}^{2+}$ transport (Davis et al., 1975), on VIP-induced glycogenolysis. As shown in Table 4, glycogenolytic activity of VIP in the presence of $\mathrm{Ca}^{2+}$ was $33 \%$, whereas the activity did not appear in the absence of the ions. The glycogenolytic activity evoked by calcium ions was suppressed with the addition of Verapamil or EDTA.

Table 1. Stimulation of glycogenolysis in response to VIP doses in cultured liver cells

\begin{tabular}{cc}
\hline $\begin{array}{c}\text { VIP concentration } \\
(\mu \mathrm{g} / \mathrm{m} l)\end{array}$ & $\begin{array}{c}\text { Increase in glucose } \\
\text { production }(\%)\end{array}$ \\
\hline 0 & $100 \pm 2$ \\
0.2 & $120 \pm 10$ \\
1.0 & $132 \pm 6$ \\
2.0 & $167 \pm 6$ \\
\hline
\end{tabular}

$2.2 \mu$ moles of glucose were produced without the addition of VIP, and taken as $100 \%$. In all cases $\mathrm{p}<0.001$.
Table 2. Combination effects of VIP, secretin and glucagon on glycogenolysis in cultured liver cells

\begin{tabular}{lcc}
\hline Exp. Addition & $\begin{array}{c}\text { Concen- } \\
\text { tration } \\
(\mu \mathrm{g} / \mathrm{m} l)\end{array}$ & $\begin{array}{c}\text { Increase in } \\
\text { glucose } \\
\text { production } \\
(\%)\end{array}$ \\
\hline 1. None & 0.2 & $100 \pm 3$ \\
Glucagon & 0.2 & $141 \pm 4$ \\
VIP & & $129 \pm 7$ \\
VIP plus glucagon & & $169 \pm 6$ \\
II. None & 0.2 & $100 \pm 1$ \\
VIP & 2.0 & $120 \pm 2$ \\
Seretin & & $130 \pm 4$ \\
VIP plus secretin & & $134 \pm 4$ \\
\hline
\end{tabular}

A rate of $100 \%$ indicates the amount of glucose produced in the absence of the hormones, that is, $2.4 \mu$ moles in Exp. I and $2.6 \mu$ moles in Exp. II $(\mathrm{p}<0.001$ in all cases).

Table 3. Effects of insulin and somatostatin on VIP-induced glycogenolysis in cultured liver cells

\begin{tabular}{|c|c|c|}
\hline Exp. & Addition & $\begin{array}{l}\text { Increase in } \\
\text { glucose } \\
\text { production } \\
(\%)\end{array}$ \\
\hline \multirow[t]{3}{*}{ I. } & None & $100 \pm 1$ \\
\hline & $\operatorname{VIP}(1 \mu \mathrm{g} / \mathrm{m} l)$ & $133 \pm 10(\mathrm{p}<0.001)$ \\
\hline & VIP plus insulin $(200 \mu \mathrm{U} / \mathrm{m} l)$ & $89 \pm 6$ \\
\hline \multirow[t]{4}{*}{ II. } & None & $100 \pm 2$ \\
\hline & Somatostatin $(2 \mu \mathrm{g} / \mathrm{m} l)$ & $88 \pm 7$ \\
\hline & $\operatorname{VIP}(2.0 \mu \mathrm{g} / \mathrm{m} l)$ & $167 \pm 6$ \\
\hline & VIP plus somatostatin & $154 \pm 3(\mathrm{p}<0.05)$ \\
\hline
\end{tabular}

The basal amounts of glucose produced in the absence of the hormones $(100 \%)$ were $2.9 \mu$ moles in Exp. I and $2.2 \mu$ moles in Exp. II.

Table 4. Calcium ion dependency of VIPinduced glycogenolysis in cultured liver calls

\begin{tabular}{lc}
\hline \hline \multicolumn{1}{c}{ Addition } & $\begin{array}{c}\text { Increase in glucose } \\
\text { production }(\%)\end{array}$ \\
\hline None & $100 \pm 2$ \\
VIP $1.0 \mu \mathrm{g} / \mathrm{ml}$ & $133 \pm 10$ \\
VIP plus Verapamil $(1 \mathrm{~mm})$ & $102 \pm 1$ \\
VIP (minus $\mathrm{Ca}^{2+}$ ) & $94 \pm 8$ \\
VIP plus EDTA (4 mM) & $100 \pm 2$ \\
\hline
\end{tabular}

(minus $\mathrm{Ca}^{2+}$ ) indicates omission of $\mathrm{CaCl}_{2}$ from the reaction mixture. 


\section{Discussion}

VIP is a highly basic peptide which resembles secretin, glucagon, and gastric inhibitory polypeptide in the amino acid sequence and biological actions, thus these hormones have been classified into the secretin-glucagon family (Grossman, 1974). With respect to the effects of VIP on carbohydrate metabolism, it has been reported that VIP had effects on serum glucose levels by inducing either insulin on glucagon release in vivo (Schebalin et al., 1974). This mechanism is consistent with the findings formed as the enteroinsular axis by Unger et al. (1967). Kerins and Said (1973) first reported that VIP had a stimulatory effect on glycogenolysis in in vitro experiments. The present study showed that VIP maximally stimulated glucose synthesis is cultured liver cells within 15 min, but that insulin and somatostatin inhibited VIP-induced glycogenolysis. Since VIP stimulated glucose production in hepatocytes, it might be considered that blood glucose levels were influenced at least in part by a direct action of VIP on liver cells in addition to the enteroinsular axis. This effect could be referred to as the entero-hepatic axis.

It has been reported that VIP activates adenyl cyclase (Desbuquois et al., 1973), and thus subsequently synthesized cyclic AMP may act as a second messenger in VIP-mediated glycogenolysis. Receptor sites for VIP on liver cell membranes were found to be identical with those for secretin but different from those for glucagon (Desbuquois et al., 1973, Bataille at al., 1974) As shown in Table 2, the combined use of VIP and glucagon indicates additive effect on glycogenolysis, but no additive effect was observed in the combined use of VIP and secretin. These findings may support the results that VIP and secretin have the same receptor sites but differ from that for glucagon.

VIP stimulates insulin secretion (Ohneda et al., 1977) and insulin concentration in the portal vein was found to be twenty-fold higher than in the peripheral vein (Blackard and Nelson, 1970). The results shown in Table 3 suggest that the decrease of glucose levels after the addition of insulin is partly caused by the inhibitory action of insulin on the VIP effect. Table 3 also demonstrates that somatostatin was inhibitory for both basal and VIP-induced glycogenolysis. Since somatostatin concentration in the portal vein was three-fold higher than in the peripheral vein (Arimura, 1978), it is also suggested that the decrease of serum glucose levels after addition of somatostatin was caused by the direct inhibitory effect of somatostatin on the liver glycogenolysis.

Verapamil is thought to block the channels responsible for the calcium influx into myocardial and smooth muscle cells (Devis et al., 1975). The present work shows that VIP-induced glycogenolysis was suppressed with addition of Verapamil or with the removal of calcium ions. This indicated that extracellular $\mathrm{Ca}^{2+}$ may play an important role in the modulation of VIP-induced glycogenolysis.

\section{Acknowledgement}

We are indebted to Prof. N. Yanaihara for the gifts of synthetic VIP and secretion.

\section{References}

Arimura, A. (1978). Clin. Endocrinol. 26, 520 (in Japanese).

Bataille, D., P. Freychet and G. Rosselin (1974). Endocrinology 95, 713.

Berry, M. N. and D. S. Friend (1969). J. Cell Biol. 43, 506.

Blackard, W. G. and N. C. Nelson (1970). Diabetes $19,302$.

Desbuquois, B., M. H. Laudat and $\mathrm{Ph}$. Laudat (1973). Biochem. Biophys. Res. Commun. 53, 1187. 
Devis, G. G., S. E. Van Obberghen and W. J. Malaisse (1975). Diabetes 24, 547.

Frandsen, E. K. and A. J. Moody (1973). Horm. Metab. Res. 5, 196.

Grossman, M. I. (1974). Endocrinology of the Gut, Charles B. Sock, Inc. New Jersey p. 65.

Hill, A. B. (1967). Principles of Medical Statistics, ed. 8, Oxford University Press, New York p. 146.

Kerins, C. and S. I. Said (1973). Proc. Soc. Expt. Biol. Med. 142, 1014.

Ohneda, A., S. Ishii, K. Horigome, M. Chiba, T. Sakai, Y. Kai, K. Watanabe and S. Yamagata (1977). Horm. Matab. Res. 9, 447.
Piper, P. J., S. I. Said and J. R. Vane (1970). Nature 225, 1144.

Said, S. I., L. P. Bosher, J. A. Spath and H. A. Kontos (1972). Clin. Res. 20, 29.

Said, S. I. and V. Mutt (1972). Eur. J. Biochem. 28, 199.

Schebalin, M., A. M. Brooks, S. I. Said and G. M. Makhlouf (1974). Gastroenterology 66, 772.

Schorr, B. A., S. I. Said and G. M. Makhlouf (1974). Clin. Res. 22, 22a.

Unger, R. H., H. Ketterer, J. Dupre and A. M. Einsentrant (1967). J. Clin. Invest. 46, 630. 